\title{
IMPACT OF THE EFFECTS OF THE RECONSTRUCTIVE SURGERY IN THE LIFE OF WOMEN WITH BREAST CANCER ${ }^{1}$
}

\author{
Aline Inocenti², Manoel Antônio dos Santos ${ }^{3}$ Edilaine Assunção Caetano de Loyola ${ }^{4}$ Paola Alexandria Pinto de \\ Magalhães ${ }^{5}$, Marislei Sanches Panobianco ${ }^{6}$
}

${ }^{1}$ Article derived from the dissertation - The experience of breast reconstruction for women with breast cancer, presented to the
Postgraduate Program of the da Escola de Enfermagem de Ribeirão Preto (EERP),a Universidade de São Paulo (USP), in 2012.
2 M.Sc. in Nursing in Public Health. EERP/USP. Ribeirão Preto, São Paulo, Brazil. E-mail: ainocenti@yahoo.com.br
${ }^{3}$ Ph.D. in Psychology. Professor of the Faculdade de Filosofia, Ciências e Letras de Ribeirão Preto. Ribeirão Preto, São Paulo, Brazil.
E-mail: masantos@ffclrp.usp.br
${ }^{4}$ Doctoral student of the Programa de Pós-Graduação em Enfermagem em Saúde Pública, of EERP/USP. Ribeirão Preto, São Paulo,
Brazil. E-mail: dipatinga@hotmail.com
${ }^{5}$ Doctoral student of the Programa de Pós-Graduação em Enfermagem em Saúde Pública, of EERP/USP. Ribeirão Preto, São Paulo,
Brazil. E-mail: paolaalexandria@yahoo.com.br
${ }^{6}$ Ph.D. in Nursing. Professor of the Departamento de Enfermagem Materno-Infantile Saúde Pública, of EERP/USP. Ribeirão Preto, São
Paulo, Brazil. E-mail: marislei@eerp.usp.br

ABSTRACT: This is a descriptive study which aimed to investigate the impact of the effects of reconstructive surgery in the life of women with breast cancer. Semistructured and audiorecorded, interviews were held with 14 women who had had mastectomies, who were registered in a rehabilitation center. Social Representation Theory was used for discussion of the data. Thematic analysis guided the analysis of the data. The categories which emerged from the interviews are related to the way in which the woman sees herself after the reconstruction, and what this meant in her life, and how she perceives its benefits and lives with the resulting limitations. The reconstruction of the breast, in some cases, allowed recovery of self-image and overcoming of the trauma caused by the disease. On the other hand, the postoperative complications gave rise to fear of further loss, fear of compromise in the sexual sphere, and fear in the perception of the reconstructed breast. The health team must offer appropriate information such that the woman may participate in the decisions regarding the operation. DESCRIPTORS: Mastectomy. Mammaplasty. Breast neoplasms.

\section{REPERCUSSÃO DOS EFEITOS DA CIRURGIA RECONSTRUTORA NA VIDA DE MULHERES COM NEOPLASIAS DA MAMA}

\begin{abstract}
RESUMO: Estudo descritivo que teve como objetivo compreender a repercussão dos efeitos da cirurgia reconstrutora na vida de mulheres com câncer de mama. Foram realizadas entrevistas semiestruturadas, audiogravadas, com 14 mulheres mastectomizadas, cadastradas em um núcleo de reabilitação. Para discussão dos dados foi utilizada a teoria das representações sociais. A análise temática guiou a análise dos dados. As categorias que emergiram das entrevistas estão relacionadas à forma como a mulher se vê depois da reconstrução e o que ela significou em sua vida, como percebe seus benefícios e convive com limitações decorrentes. A reconstrução da mama, em alguns casos, proporcionou recuperação da autoimagem e superação do trauma causado pela doença. Já as complicações pós-operatórias suscitaram medo de nova perda e comprometimentos na esfera sexual e na percepção da neomama. A equipe de saúde deve oferecer informações adequadas para que a mulher possa participar das decisões a respeito da cirurgia.
\end{abstract}

DESCRITORES: Mastectomia. Mamoplastia. Neoplasias da mama.

\section{IMPACTO DE LOS EFECTOS DE LA CIRUGÍA RECONSTRUCTIVA EN LA VIDA DE MUJERES CON NEOPLASIAS DE LA MAMA}

RESUMEN: Este estudio objetivó comprender el impacto de los efectos de la cirugía reconstructiva en la vida de mujeres con cáncer de mama. Se realizaron entrevistas semi-estructuradas, audio-grabadas, con 14 mujeres que se sometieron a la mastectomía y estaban matriculadas en un centro de rehabilitación. Para la discusión de los datos se utilizó la teoría de las representaciones sociales. El análisis temático guió la análisis de los datos. Las categorías que surgieron de las entrevistas se relacionan con la forma en que la mujer se ve después de la reconstrucción y lo que esto ha significado en su vida, como ella se da cuenta de sus beneficios y cómo se vive con las inevitables limitaciones. La reconstrucción de la mama, en algunos casos, proporcionó la recuperación de imagen de la sí misma y superación del trauma causado por la enfermedad. Ya complicaciones postoperatorias plantearon temores de una nueva pérdida y alteraciones en la esfera sexual y en la percepción de la mama reconstruida. El equipo de salud debe proporcionar informaciones adecuadas para que las mujeres puedan participar en las decisiones acerca de la cirugía.

DESCRIPTORES: Mastectomía. Mamoplastia. Neoplasias de la mama. 


\section{INTRODUCTION}

Breast cancer, when discovered at an advanced stage, can lead to the undertaking of radical surgeries such as mastectomy, as well as compromising the results of the therapy and reducing the chances of survival. In the light of the need for the total removal of the breast, the woman has to coexist with the mutilation of an organ which symbolizes her womanliness and motherhood in Western society, ${ }^{1}$ entailing a series of psychological, physical and social consequences related to body image.

The scientific community is increasingly concerned with the development of new techniques, capable of creating a breast which is similar in form and appearance to the natural breast; there are, nowadays, various possibilities offered by surgical oncology. These include both immediate and later surgeries, with or without the use of an expander, silicone implants and grafts with autologous tissues (undertaken with tissues obtained from the abdomen or from the dorsal muscle), undertaken with the objective of giving the woman back the breast which was removed.

The reconstruction of the breast may restore the patient's shape and physical integrity, among other benefits which have been shown. In this scenario, psychological well-being performs a crucial role, as the breast reconstruction can reduce the impact caused by stigmas and by the sequelae left by the surgical oncology. With the dissemination of the advances achieved through surgical technique, increasing numbers of patients are benefiting. ${ }^{2}$

There are many reasons why women undertake reconstructive surgery. One of the most common is the fact that it constitutes an alternative which makes it possible to reduce the impact which the amputation, mutilation or deformity caused by the mastectomy imposes on the image which the patients have of themselves; thus aiming for the restoration of self-image and the social function of the breast. ${ }^{3}$ However, this type of surgery, in spite of providing various benefits to the woman, can, in some situations, cause serious compromises.

In relation to the physical complications entailed by the surgery, one can observe some specific issues related to each type of procedure. In the cases of reconstructions which use expanders and/or silicone prostheses, complications may occasionally arise, such as: infection, extrusion of the expander, leaking, and capsular contracture and deformity after the expansion. The autologous reconstructions, on the other hand, can lead to complications such as seromas, pulmonary thromboembolism, partial or total necrosis of the flap, infection, hematoma and changes in the donor area, ${ }^{4}$ as well as the loss of the tactile sensitivity of the new breast.

As a consequence, the surgery for breast reconstruction has advantages and disadvantages which directly influence the woman's physical, emotional and social aspects. For this reason, the operation and its consequences have been studied, mainly in the context involving practices and techniques. ${ }^{3-4}$ However, it is understood that the psychological implications have equally importance and, must be taken into account in all the phases of the care for the woman facing breast cancer.

The literature on the factors involved in breast reconstruction is significant; however, the aspects related to the subjective and sociocultural conditions of the women who undergo mastectomy remain little known. Social Representation Theory (SRT) is one of the theoretical-methodological conceptions which may contribute to the understanding of the specific characteristics of the sociocultural dimension involved in healthcare. In this theoreticalmethodological perspective, the SR are modalities of practical knowledge, geared towards communication and understanding of people's social, material and ideational context. They consist of the forms of knowledge manifested as cognitive elements, images, concepts, theories and categories, but which cannot be reduced to the cognitive components of the representation..$^{5-6}$

The SR are widely used in the health field, principally in the chronic conditions, such as breast cancer. In this theoretical framework, attention is focused on the psychosocial aspects involved in facing the disease, which are increasingly valued in clinical practice, especially for the understanding of the factors related to the patients' quality of life..$^{5-6}$

To consider the point of view of the woman, to whom the health actions undertaken by the nursing professional are directed, is an important step towards the implementation of quality care. In investigating the meanings attributed to breast reconstruction, it is possible to learn about the patients' expectations, and the risks and benefits perceived in relation to the surgical intervention, as well as regarding other aspects which influence the perception of the course of the disease.

In investigating the SR it is necessary to take into account that, under specified circumstances, some aspects which constitute the representations of breast reconstruction are emphasized, while others cease to be focussed upon. As a result, under- 
standing the SR relating to this procedure makes it possible to capture the tensions and conflicts which permeate the field of the practice in health, regarding the treatment of breast cancer. This knowledge may contribute to furthering knowled ge regarding the conflicting points, the contradictions and oscillations which characterize the patients' behavior, sometimes regulated by the concern with health, and at other times dominated by other values, associated with the areas of human experience which are affected by the treatment, such as body image, aesthetic values, relational competence and the lifestyle of the woman affected. In a broader sense, the understanding of this mobile structure, observed in the dynamic of production and reproduction of the SR, may cause reflection regarding the stability of the advice offered by the health professionals in relation to the disease and to the treatment.

In the light of this situation, this study aimed to understand the impact of the effects of the reconstructive surgery in the life of women with breast cancer.

\section{METHOD}

This is a descriptive study with a qualitative approach, undertaken with women who had undergone breast reconstruction, and who were registered in a center for rehabilitation for women who have undergone mastectomy, itself part of a university in the interior of the State of São Paulo. In this service, the women receive multi-professional assistance and undertake activities which help them to overcome the physical and emotional sequelae of the disease, through exercises for prevention and control of lymphedema, correction of the limitations in amplitude of arm and shoulder movements, lymphatic drainage, bandaging of the homolateral arm to the surgery, and high-voltage electrical stimulation. The women also participate in discussion groups, in which they find a space for sharing experiences and seeking solutions to doubts regarding becoming ill through cancer, and the treatments. Supervised excursions are also undertaken, as are commemorative events and handicraft fairs, organized by the team and by the service users themselves.

In the period in which the study was undertaken, the psychosocial rehabilitation center had 1103 registered service users, of whom 93 had undergone breast reconstruction. For the selection of the women, the registration system was used to identify those who met the inclusion criteria: to be aged over 18 years old, to have undergone breast reconstruction surgery following surgery for breast cancer, and to be able to express themselves verbally.

After this preliminary selection, the participants were selected by convenience. One of the researchers, who worked as a volunteer in the center, made a search for potential participants. The women were approached in the interval between routine group activities or were invited by telephone to participate in the study. In this way, 14 women participated in the research. It is important to emphasize that all those who were invited accepted to participate in the study.

As this is qualitative research, the definition of the number of participants depended on the understanding of the phenomenon. As a result, as the same units of meaning and repetition of content emerged, it was considered that data saturation had occurred, and data collection was finalized.

Semistructured and audiorecorded interviews were held. These were later transcribed in full for the immediate beginning of codifying the data, in December 2010 - August 2011. The interviews had a mean duration of 50 minutes, and were guided by a script elaborated by the researchers, divided into two parts: the first contained data characterizing the study participants (age, marital status, occupation and time since surgery, among other information); the second was made up of a trigger question: tell me how it was for you to undergo breast reconstruction. In this investigation, the trigger question only guided the objective of the study explored. Further questions were added with the aim of clarifying and forming a basis for the experiment.

For the analysis of the information, the decision was made to use thematic content analysis. ${ }^{7}$ In this type of analysis, one seeks to deconstruct the account and capture what lies behind the content manifested. ${ }^{8}$

As stipulated by this method, exhaustive readings were undertaken of the material, being based on the initial questions and the reformulation of hypotheses, which led to the correction of interpretive directions or to further inquiries. Next, the researchers specified the units of meaning (keyword or phrase), the units of context (understanding of the context of the record unit), the excerpts, the way of categorization, the mode of codification and the general theoretical concepts which guided the analysis.

The classificatory operation took place in the phase of exploration of the material, seeking to reach the center of understanding. Of the text in this stage, the formation of categories took place, these being significant expressions or words through which the 
content of an account is organized. This phase was followed by the classification and aggregation of the data, with the theoretical or empirical categories being chosen, which were responsible for the specification of the themes referring to the positive or negative effects of the breast reconstruction.

In order to guarantee confidentiality in relation to the participants' identity, fictitious names were attributed, following interview order, in alphabetical order.

All of the ethical aspects contained in Resolution 196/96, of the Conslho Nacional de Saúde - Brazil, were respected. ${ }^{9}$ Data collection was begun following approval by the Research Ethics Committee of the institution with which this study's researcher maintains a link, under Protocol $n^{\circ}$ 1168/2010.

\section{RESULTS AND DISCUSSION}

\section{Characterization of the women of this study}

The participants' age varied between 42 and 60 years old. Half of the women were married, and the majority had their own income. In relation to educational level, only three had achieved higher education, and one had concluded postgraduate study.

The time since diagnosis with breast cancer varied between two and 16 years, while the time since undertaking surgery for removing the cancer varied between one and 16 years. The time since undertaking breast reconstruction varied between one and 13 years, and the most frequent type of surgery was reconstruction with a silicon prosthesis, with a total of seven women who had undertaken this procedure, one of these participants had used an expander prior to the placing of the prosthesis. Five women had undergone breast reconstruction with the transverse rectus abdominis myocutaneous flap, and two women had undergone reconstruction with flap obtained from the latissimus dorsi muscle, with the concomitant implantation of the silicon prosthesis.

Regarding the undertaking of the reconstructive surgery, ten women underwent immediate reconstruction (during the same surgical act as the removal of the breast) and four had undergone later reconstruction (months or years after the mastectomy). Only eight of the 14 women undertook the reconstruction using the public health system, and of these, five finalized the reconstructive surgery with the reconstruction of the areola-mammary complex and the symmetrization of the breasts.

Based on the reports obtained in the interviews, the categories and subcategories emerged related to the impact of the effects of the reconstructive surgery in the life of the women with breast câncer, which are described below.

\section{The benefits of breast reconstruction}

\section{The recovery of self-image}

Recovering the breast which was lost as a result of the cancer gives the woman back her self-esteem. Although, in some cases, the breast no longer had the function of breast-feeding, the breast is considered important for the construction of self-image. The feeling of being whole once more helps the woman to accept her new body image and overcome the mutilation caused by the surgery.

[...] my graft is already part of my body, where it is. Now, even though it is stitched around, the marks, you feel much better, it seems that it is normal, you feel your body normal (Anita).

It was noted that some women were able to define a parameter for accepting the new breast, comparing it not to the breast which was not operated on, but with the breast that was extirpated in the surgery. In this way managing to obtain satisfaction with the result of the reconstruction, which brought back the desire to look at themselves in the mirror and the gratification caused by feeling womanly once more.

For me, it is fine as it is. I wish everybody had the chance for reconstruction. I think that it helps self-esteem a lot. I think it is very important. I'm satisfied, because my breast's function was to have children, breast-feed, and now, at my age, I think that it is okay (Fatima).

For many women, the reconstruction of the breast reduces the trauma of the mutilation, allows the recovery of self-esteem and self-image and restoring feelings of attractiveness and femininity, as well as increasing the wish to dedicate oneself to aesthetic care. As a result, women opt for reconstruction in the attempt to reduce the negative feelings triggered by the disease and its treatments, to improve self-esteem, overcome the lack of the breast and facilitate the use of their wardrobe. ${ }^{10}$

It was observed, in some cases, that the feeling of loss and mutilation caused by the mastectomy is mitigated; and the women feel greater security and freedom for frequenting social environments. 
[...] I think that the reconstruction helps us not to feel mutilated. I think that, emotionally, reconstruction is very important for women, even if it becomes different and so on, but this feeling of volume, that we continue to have... Because you wear your clothes, you feel that you have the breast (Martha).

The women make it clear that it is not necessary for the breast to be exactly as it was before the surgery, and emphasize that the volume offered by the prosthesis or flap provides the women with confidence that they can use various types of clothes, including those which expose part of the new breast, without needing to worry whether the prosthesis will shift or appear, or even fall out. This concern shows clearly in the report of one woman who had used an external breast prosthesis before undergoing the reconstructive surgery.

God! This one here [the reconstructed breast] is much better, the old one [the external prosthesis] doesn't look good. The external one doesn't stay properly [in place], it doesn't look right. This one here is perfect, if I put on a particular item of clothing, if I put on a bikini, it looks perfect. Yes, I wear bikinis, a little one, and it looks good (Joanna).

The restoring of the body integrity influences the women's general satisfaction and, although they cannot recover the lost breast or wipe away the scars resulting from the operations, the obtaining of volume, shape and texture similar to the natural breast contributes decisively to the recovery of self-esteem. ${ }^{11}$

Having the breast back, even if incomplete or with scars, causes some women to feel secure and encouraged to maintain or initiate an affectivesexual relationship with a partner, principally when these women are young and have an active sex life.

[...] The reconstruction brought me great benefits, helped me to have a better life, gives me pleasure to live, to date, pleasure in a lot of things. I'm not going to cease having a sex life, of having my partner, of going out, because of the breast (Bruna).

The security to recommence sexual activities with the partner, or to initiate a new affective relationship, after undergoing reconstructive surgery, suggests that it is possible to recover the physical and psychic integrity after removal of the breast. For many women, to exercise sexuality fully and to feel oneself to be attractive, are more important aspects than feeling comfortable using décolletage, than attracting the sexual desire of the partner, and even more relevant than their own physical appearance. ${ }^{12}$

\section{Overcoming the disease}

When faced with the diagnosis of breast cancer, the fear of the breast being amputated was one of the most recurrent feelings reported by the women. To leave the operating theater with a new breast representated a powerful encouragement to recover faster, and helps them to cope better with the treatment and overcome the trauma determined by the disease.

[...] I was pretty happy to know that I was going to get better, I would be okay, because I saw my breast. It was very important to me. The reconstruction, you know? It even helped me to get better. Within a few days I was already out and about, I was walking, I was carrying on with my normal life. Everything is good in my life (Bruna).

To look at the empty space left by the mastectomy brings back memories of the disease and the suffering caused by breast cancer. The breast reconstruction, in filling this bodily gap, contributes to the woman being able to overcome the negative feelings which permeate the experience of the disease. In this regard, the reconstruction is seen as the coronation to successful treatment, and it is possible to perceive, in some accounts, the association of the procedure with the resolving of the breast cancer, that is to say, the subjective feeling of having definitively freed oneself of this feared disease.

[...] There you are with both your breasts, I think this is much better than looking and seeing that empty space, because you look all the time and you see, you know, that... And you remember that you don't have that breast because you had cancer. Now, if you cover that space, it is something that has been overcome. I think that it is [...] really the coronation of a treatment, you know? It's something that you look at and say: 'No! I was treated, but it is there, I still have my breast' (Martha).

Some women believe that the surgical treatment of mastectomy symbolizes the cure of the breast cancer. They hope that this cure may be obtained through removing the affected organ, which could be said to represent the eradication of the disease. ${ }^{13}$ The results of the present study corroborate the findings in the literature. Hence, in reconstructing the breast, the women believe that they acquire greater tranquility and self-confidence for resuming their normal life, which caused them to be able to give the new breast the representation of the end of the disease and the final stage of the treatment - and, in this way, their lives were also reconstructed. 


\section{The problems entailed by the surgery}

\section{Dissatisfaction with the appearance of the new breast}

The transformation of the body is a meaning to be constantly negotiated by the women who undertake breast reconstruction, as this is an issue of a body which has been changed, reconstructed. Although it promotes the recomposition of the mutilated body, the autologous reconstruction, in some cases may be perceived, felt and represented as yet one more mutilation, given the compromising of a healthy part of the body for the removal of the flap, obtained from the latissimus dorsi muscle or from the rectus abdominis. ${ }^{14}$

Some participants' accounts showed that they saw no similarity between the reconstructed breast and the natural one, seeing the new breast as a piece of meat sewn onto their body.

It doesn't look like a normal breast. It's meat, a piece of meat. I find the color, even the tone, you know, quite different (Eva).

[...] It gives the impression that it leaves you less of a woman, because as a result of the surgery it seems that you are all cut up, do you understand? I wish I had the breast that I had before (Bruna).

As the operation for removing the tumor leaves scars and inevitably involves the loss of adjacent tissues, the prosthesis, when implanted in this space, often fails to provide an appearance which is symmetrical to the other breast, that is, its appearance is very different to that of the contralateral breast. In the cases of women in whom were used silicon prostheses for breast reconstruction, the feeling reiterated is of something not being right, which may be exemplified in the account below.

[...] one negative point that I find, like, is that a prosthesis is not a breast. That means that it is a thing that is not natural, it is an artificial thing. We always hope for something better. Like it or not, in my heart of hearts, I hoped that it would be as close as possible to the breast, but it isn't, it is different (Louisa).

There is also the aesthetic dissatisfaction on the part of some women who undergo reconstruction with the silicon prosthesis, leading them not to acquire the expected body image. ${ }^{15}$ This dissatisfaction with the appearance of the new breast caused Yvonne, a participant in the study, not to let her partner see or touch the breast. As she did not accept the imperfect breast, she also considers it difficult to believe that her companion will accept it, and as a result does everything she can to hide it.
[...] no, he never said [the partner], he has never touched it [the breast], I don't let him [touch the breast], I don't even let him see it. I don't use low-cut blouses, because they are not equal, so I disguise them. I'm ashamed, I show the normal one, but this one here [the reconstructed breast], there is that space. I only show it from the side (Yvonne).

The woman's dissatisfaction regarding the reconstructed breast may be related to compromise in the results of the operation, such as, for example, the presence of visible scars, the lack of naturalness in the appearance, and changes in sensitivity. It is possible that the problems with body image continue for a long period after the operation, with a feeling of depreciation of womanliness and lack of sexual desire persisting. ${ }^{16}$

Sexuality and body image are essential components of identity, of self-concept, and of life's relationships. These aspects of personality are severely compromised by breast cancer. As this is an issue of important aspects in the experience of the woman with breast cancer, sexuality and body image are themes which must be addressed by the health professionals and discussed with the patient and her partner. ${ }^{17}$ There are cases, however, in which the deformity of the breast does not affect the sexual relationship, but, rather, the woman's coexistence in society. The woman, often, faces the cultural aspects referent to the construction of female identity, and which are without doubt implicated in the relationship with the disease of cancer, which has highly specific symbology and cultural meaning..$^{18}$

[...] we have to use artifice so that people don't ask us anything. You always put on a necklace, something which will call attention to the person and not the scar (Denise).

As a strategy so as not to feel different in the face of society, the women in this study used artifice to disguise the imperfections resulting from the surgery, such as irregularities, difference in the size of the breasts, and the presence of scars, which stopped other people from looking at them with strangeness or asking about anything related to the disease.

\section{The fear of losing the breast again}

The occurrence of problems related to surgery, such as rejection of the prosthesis or of the graft, or even the worry concerning the possibility of these problems occurring, raises the issue of the fear shown in the beginning of the treatment. The woman faces the possibility of losing the reconstructed breast as a palpable threat to her physical 
and psychic integrity. Her concern comes to be directed to the appearance of the new breast, should it be lost, and to the possibilities of there being no further alternatives for a further reconstruction of the breast.

\section{[...] I was really scared, I was scared of it all rotting} there and me losing the entire breast. What I was scared of was not losing the breast, it was of the hole being there. Where would I get hold of tissue? (Eva).

[...] I was scared of losing everything. We say: 'Oh my God! And what happens now, if I lose all this, if this skin doesn't 'take'? How is it going to look?' We are scared of infection, we're scared of fever, you get kind of intensely aware of these things (Karen).

When they face the complications which can result from the reconstructive surgery, the women not only see themselves faced with the possibility of having to cope once more with the treatment and the rehabilitation, but also return to experiencing the extreme vulnerability to which they were previously exposed. ${ }^{19}$

I am still scared of undertaking the next stage of surgery. I did the operation, but don't feel that the silicone has been put in. Now, imagine if because of vanity, in an attempt to look better, I were to lose the breast, because of rejection? I think that it is not important now (Fatima).

The fear of losing the breast again is reflected in the decision not to continue with finalizing the reconstructive surgery. In this regard, some of the reasons, such as advancing age and the benefit already gained with the first stage of reconstruction, even if unfinished, cause the women to believe that the surgery for finalizing the process would have a merely aesthetic objective, and that they would be submitting themselves to an unnecessary risk of losing the breast once more, were there to be complications.

It is important also to emphasize that the problems related to body image, experienced after the surgery, can also result in a lack of interest in a further intervention, such as the reconstruction of the areola-mammary complex. ${ }^{16}$ However, another study has shown that the women who undergo breast reconstruction presented less anxiety and depression than those who underwent only mastectomy. ${ }^{20}$

The surgical procedure in the treatment of breast cancer must provide not only the reduction or exeresis of the tumor, but, also the best aesthetic result possible, so as to reduce the potential physical and emotional harm.

\section{The loss of the breast's sensitivity}

The loss of the breast's sensitivity was seen to be a common consequence for all the women who participated in the present study. The difficulty was observed, on their part, of accepting the implanted tissue as a breast, given that the graft does not offer from the beginning, and in some cases, permanently, the sensitivity as the other regions of the body. The cold skin, and the presence of scars, in conjunction with the absence of sensitivity, provoked in some women the feeling that the graft corresponds to dead skin, which is not part of their body.

[...] It is because you lose the sensitivity. As a result, even though you have the breast, you don't have that normal sensitivity that you used to. So that is all that we feel, because it is as if it really was dead skin (Anita).

[...] It is cold, the sensitivity is very different. [...] the temperature is different, so it gives the feeling that it is not part of your body, because it is cold (Hilda).

It was also observed that some women have difficulty in exercising their sexuality when the breast's sensitivity is compromised. A part of the body, which previously promoted a feeling of pleasure, comes to give a feeling of discomfort and other uncomfortable feelings, being able to cause them to associate the lack of sensitivity with the disease which the breast had, every time they are touched.

[...] Because this is part, it is part of our sexuality. The breast, it is part of a load of things and we have a lot of sensitivity in the breast. It's the same thing in sexuality, it has a lot of sensitivity. When I am touched there, I feel it quite a bit. But now, it is rather compromised (Bruna).

When questioned about the return of the sensitivity in the reconstructed breast, the women mentioned feeling discomfort when stimulated in this part of the body. A proportion of them perceives the reconstructed breast as real, but few are able to experience sexual sensations in this breast. ${ }^{21}$

Some participants, in resuming their sex lives following the surgery, felt difficulty due to the feeling of rejection on the part of the partner. Even with the breast reconstructed, they do not allow it to be touched due to the discomfort provoked by the absence of the sensitivity. ${ }^{22}$ As a result, they come to coexist and to relate with a new body reference, in which the pleasure and the libido become diffused throughout the body ${ }^{23}$ and parts which were previously erogenized come to have a reduced sensitivity.

The initiative to explore other erogenous areas was mentioned by the women in this study, reflecting the ability to adapt to their new reality. The acceptance and help of the partner, at this delicate time, 
was represented as being of fundamental importance for the discovery and acceptance of the new body.

There are other ways [laughs]. Ah, I think, you know, there are other more sensitive parts (Giselle).

He [the husband] plays with them... [laughs]. He caresses the other [breast], but does not forget this one. Although I don't feel it, he also plays with this one. He doesn't just touch the other one. So, for me, it is as it used to be (Joanna).

Feelings of friendship, respect, understanding and tenderness on the part of the partners are perceived and represented as a necessary support in order for the women to be able to overcome the obstacles and overcome the physical and psychosocial sequelae left by the surgery. ${ }^{24}$

It is important, therefore, to think of breast cancer in all its aspects, as it is a disease which affects the woman not only in the physical ambit, but which also compromises the relationship which she has with her body image and with different aspects of her social and affective life. ${ }^{25-27}$

As limitations of this study, emphasis is placed on the fact that it used a convenience sample, as well as the fact that the women who participated in the study attended a psychosocial rehabilitation group, in which they received information about cancer and its implications, as well as being in constant contact with other women who had undergone breast reconstruction. In spite of these limitations, it is believed that this study's results can contribute to improving the quality of care for women with breast cancer, through offering the health professionals new information regarding the physical, emotional and social consequences associated with breast reconstruction.

\section{CONCLUSION}

The reconstruction of the breast contributed to some women recovering their self-esteem and the feeling of being complete once more, helped them to recover self-image and to overcome the trauma caused by the breast cancer, giving them the security to preserve or initiate an affective or sexual relationship with a partner.

The complications faced in the postoperative period discouraged some of the participants from finalizing the reconstructive surgery, and gave rise to the fear of a further loss. The scars and deformities in the breast caused concern, worry and dissatisfaction, and the loss of the sensitivity of the flap caused, in some cases, compromises in the sexual sphere and in the perception of the new breast.
The health professionals must extend their knowledge regarding this issue and seek continuous improvement regarding the topic. It is important that the health teams should develop strategies for informing women about the possibility and the right to undergo breast reconstruction, clarifying for some the advantages and disadvantages of the surgery, such that they may be genuinely involved in the decision-making related to the treatment.

\section{REFERENCES}

1. Azevedo RF, Lopes RLM. Concepção de corpo em Merleau-Ponty e mulheres mastectomizadas. Rev Bras Enfermagem. 2010 Nov-Dez; 63(6):1067-70.

2. Angheben E, Garnica G. Oncoplastia mamaria. Rev Argent Cancerol. 2014; 42(1):41-8.

3. Gonzalez E, Rancati A. Cirugía oncoplástica de mama. Buenos Aires (AR): Ediciones Journal; 2014.

4. Figueiredo,PRA. Reconstrução mamária em câncer de mama e suas complicações no Hospital Servidor Público Municipal de São Paulo. São Paulo: s.n; 2012.

5. Moscovici S. A psicanálise, sua imagem e seu público. Petrópolis (RJ): Vozes; 2012.

6. Jodelet D. Representações Sociais: um domínio em expansão. In: Jodelet D, organizador. As representações sociais. Rio de Janeiro: Eduerj; 2002. p.17-44.

7. Bardin L. Análise de conteúdo. Lisboa (PT): Edições 70; 2010.

8. Minayo MCS. O desafio do conhecimento: pesquisa qualitativa em saúde. São Paulo: Hucitec; 2006.

9. Ministério da Saúde (BR). Resolução no . 196/96: dispõem sobre pesquisa envolvendo seres humanos. Brasília (DF): MS; 2009.

10. Oliveira RR, Morais SS, Sarian LO. Efeitos da reconstrução mamária imediata sobre a qualidade de vida de mulheres mastectomizadas. Rev Bras Ginecol Obstet. 2010 Dez; 32(12):602-8.

11. Sánchez EC, Camacho AR, Ferrer AD, Gomá JRB, Beltrami CT, Belmonte GP, et al. Satisfacción en pacientes con reconstrucción mamaria con colgajo D.I.E.P. Cir Plast Iberolatinoam. 2006; 32(3):169-78.

12. Huguet PR, Morais SS, Osis MJD, Pinto Neto AM, Gurgel MSC. Qualidade de vida e sexualidade de mulheres tratadas de câncer de mama. Rev Bras Gincecol Obstet. 2009; 31(2):61-7.

13. Toriy AM, Krawulski E, Viera JSB, Luz CM, Sperandio FF. Percepções, sentimentos e experiências físicoemocionais de Mulheres após o câncer de mama. J Human Grow Development. 2013; 23(3):303-8.

14. AurelianoWA."...EDeus criou a mulher: reconstruindo o corpo feminino na experiência do câncer de mama". Rev Estud Fem. 2009; 17(1):49-70.

15. Colakoglu S, Khansa I, Curtis MS, Yueh JH, Ogunleye A, Haewyon C, et al. Impact of complications on 
patient satisfaction in breast reconstruction. Plast Reconstr Surg. 2011; 127(4):1428-36.

16. Heijer MD, Seynaeve C, Timman R, Duivenvoorden HJ, Vanheusden K, Linthorst MT, et al. Body image and psychological distress after prophylactic mastectomy and breast reconstruction in genetically predisposed women: a prospective long-term followup study. Eur J Cancer. 2012 Jun; 48(9):1263-8.

17. Ferreira SMA, Panobianco MS, Gozzo TO, Almeida AM. Sexuality of women with breast cancer: analysis of scientific production in nursing. Texto Contexto Enferm [Internet]. 2013 Jul-Set [cited 2015 Apr 22]; 22(3):835-42. Available from: http://www. scielo.br / scielo.php?script=sci_arttext\&pid=S010407072013000300033\&lng=en\&nrm=iso\&tlng=en

18. Silva LC. Câncer de mama e sofrimento psicológico: aspectos relacionados ao feminino. Psicol Estud. 2008; 13(2):231-7.

19. Silva G, Santos MA. “Será que não vai acabar nunca?”: perscrutando o universo do pós-tratamento do câncer de mama. Texto Contexto Enferm. 2008; 17(3):561-8.

20. Delgado JF, Pedraza MJL, Blasco JA, Aragones EA, Mendez JIS, Miralles GS, et al. Satisfaction with and psychological impact of immediate and deferred breast reconstruction. Ann Oncol. 2008; 19:1430-4.

21. Gahm J, Jurell GR, Wickman M, Hansson P. Sensitivity after bilateral prophylactic mastectomy and immediate reconstruction. Scand J Plast Reconstr Surg Hand Surg. 2007; 41(4):178-83.

22. Junqueira LCU, Vieira EM, Giami A, Santos MA. Análise da comunicação acerca da sexualidade, estabelecida pelas enfermeiras, com pacientes no contexto assistencial do câncer de mama. Interface Comun Saúde Educ. 2013; 17(44):89-101.

23. Vieira EM, Ford NJ, Santos MA, Junqueira LCU, Giami A. Representations of nurses regarding sexuality of women treated for breast cancer in Brazil. Cad Saúde Pública. 2013; 29(10):2049-56.

24. Gasparelo C, Sales CA, Marcon SS, Salci MA. Percepções de mulheres sobre a repercussão da mastectomia radical em sua vida pessoal e conjugal. Ciênc Cuid Saúde. 2010; 9(3):535-42.

25. Costa SR, Jimenéz F, Ribeiro JLP. Imagem corporal, sexualidade e qualidade de vida no cancro da mama. Psic Saúde Doenças. 2012; 13(2):327-39.

26. Souza BF, Moraes JAM, Inocenti A, Santos MA, Silva AEBC, Miasso AI. Women with breast cancer taking chemotherapy: depression symptoms and treatment adherence. Rev Latino-Am Enfermagem. 2014; 22(5):866-73.

27. Bergerot CD, Araujo TCCF, Tróccoli BT. Assessment of distress among chemotherapy patients: a comparative study of gender. Paidéia (Ribeirão Preto). 2014; 24(57):56-65. 